\title{
Identification Chemical Compositions of Lemongrass Plant (Cymbopogon nardus L.) Dawan Tribe, Oenenu Village, North Central Timor Regency
}

\author{
*Noviana M. Obenu, Eduardus Edi \& Risna E. Adu
}

Kimia/FAPERTA-Universitas Timor, NTT - Indonesia 85613

Received 23 March 2021, Revised 20 April 2021, Accepted 20 May 2021

doi: 10.22487/j24775185.2021.v10.i2.pp93-97

\begin{abstract}
Lemongrass (Cymbopogon nardus L.) is a local natural resource used by the Dawan tribe as an alternative for mosquito repellent. The utilization of these plants cannot be separated from the content of compounds found in these plants. Therefore, it is necessary to analyze the content of bioactive compounds from lemongrass (Cymbopogon nardus L.). This research method includes sample preparation, isolation and identification of compounds, and antioxidant activity analysis. The results of this study that there were three main components of citronella oil, namely geraniol, citronellol, and citronellal, with a higher percentage of geraniol, namely $18.82 \%$. The compounds contained in lemongrass oil have a weak antioxidant activity with $I C_{50} 681.48 \mu \mathrm{g} / \mathrm{mL}$.
\end{abstract}

Keywords: Cymbopogon nardus L, steam-distillation, GC-MS, bioactivity, antioxidants

\section{Introduction}

Cymbopogon nardus L. known as lemongrass, is a plant included in spices and is widely used as a cooking spice. This plant is included in the group of essential oil-producing plants (Mahalwal \& Ali, 2003; Nakahara et al., 2003; Sembiring \& Manoi, 2015). The compounds produced in lemongrass oil are reported to have bioactive properties (Bota et al., 2015; Setyaningsih, 2007; Aulung et al., 2014). These compounds include citronellal compounds, citronellol, geraniol (Nakahara et al., 2003; Mahalwal \& Ali, 2003; Mirghani et al., 2012).

Based on research, the compounds produced have activity as antibacterial, antimicrobial and antifungal, antilarvicide (Wei \& Wee, 2013; Arcani, et al., 2017; Aulung et al., 2014; Iskarlia \& Rahmawati, 2014). Chemotaxonomically (the content of chemical compounds in one taxa/tribe), the chemical affinity (similarity) of one species in one genus or one family has the same pattern of molecular structure formation. Qualitatively, the content of the compounds will be the same, but the quantity of each compound can be different. This is possible due to several factors, among others, due to the influence of the environment in which the plant grows, the part of the plant, and the geographical location of a place (Venkataraman, 1972).

The Dawan tribe "Atoin Meto" in Oenenu Village, North Central Timor Regency, East Nusa Tenggara Province, has used much lemongrass as an alternative for mosquito repellent. The use of this plant has encouraged people to plant it as a superior commodity and make lemongrass a local resource that can improve the household economy. Furthermore, the use of this plant is maximized by simple distillation to produce citronella oil. The products of the citronella oil distilled by the local community have been marketed. Kolo et al. (2018) has conducted research to test the antibacterial activity of refined lemongrass oil. In the results of this study, it was reported that the lemongrass oil of the Dawan tribe community had positive antibacterial activity. The results of the analysis of the content of the bioactive compounds in lemongrass have not been reported. Apart from the unreported range of compounds, it is also necessary to test other bioactivities such as antioxidants.

The aim of the present paper is to give a description of the content compounds in lemongrass oil and what are the other bioactive properties of the compounds contained in the lemongrass oil. The purpose of this research needs to be done so that the compounds contained in lemongrass oil can be identified to support the market quality of lemongrass oil increase the knowledge of the local community in the development and preservation of superior commodities and find out other bioactive properties of lemongrass oil.

\section{Methods}

This research will be conducted at the local community's citronella oil refinery, and the refining

${ }^{*}$ Correspondence:

Noviana M. Obenu

e-mail: noviobenu3@gmail.com

(c) 2021 the Author(s) retain the copyright of this article. This article is published under the terms of the Creative Commons Attribution-NonCommercial-ShareAlike 4.0 International, which permits unrestricted non-commercial use, distribution, and reproduction in any medium, provided the original work is properly cited. 
will be carried out in the laboratory of the Faculty of Agriculture (FAPERTA), University of Timor. Sampling of citronella plants in Oenenu Village, Bikomi Tengah District. This research is laboratoryfield research that is carried out in several stages, starting with the sample preparation stage, then the sample distillation with the local community, followed by the compound analysis stage with GCMS and bioactivity testing as an antioxidant.

The materials used in the study were Cymbopogon nardus L, pro analysis anhydrous $\mathrm{Na}_{2} \mathrm{SO}_{4}$ (Merck), helium gas, 2,2-diphenyl-1picrylhydrazyl (DPPH) $5 \times 10^{-4} \mathrm{M}$ (Merck), $0.1 \mathrm{M}$ acetate buffer solution ( $\mathrm{pH} 5.5$ ) (Merck), ethanol, Plasmodium falciparum strains $3 \mathrm{D} 7, \mathrm{DMSO}, \mathrm{O}_{2}$ $5 \%, \mathrm{CO}_{2} 5 \%$ and $\mathrm{N}_{2} 90 \%$.

\section{Extraction Procedures}

\section{Sample preparation}

Samples of lemongrass leaves and stems were taken by cutting the clumps near the ground. The plants which have been obtained are then washed, then cut into small pieces

\section{Extraction}

A total of $22 \mathrm{~kg}$ of dried lemongrass leaves and stems were isolated by the steam distillation method (Nakahara et al., 2003). The leaves and stems of the lemongrass were put into a distillation container of lemongrass oil that had been filled with water, then heated over low heat. During heating, a condensation process occurs in the condenser, and the distillate was obtained, which was then accommodated in the Erlenmeyer. The oil that has been obtained needs to be freed again from the remaining water by adding anhydrous sodium sulfate $\left(\mathrm{Na}_{2} \mathrm{SO}_{4}\right)$ to bind water molecules. This water-free oil was then used to test for antioxidant and antimalarial activity. In addition, it is used for compound analysis by GC-MS.

\section{Identification of lemongrass oil chemical compounds by $G C-M S$}

The obtained citronella oil was analyzed using GC-MS with the following settings: helium gas as a carrier gas, gas flow rate $1 \mathrm{~mL} / \mathrm{min}$, injector temperature $300{ }^{\circ} \mathrm{C}$, detector temperature $200{ }^{\circ} \mathrm{C}$, column temperature set from $35^{\circ} \mathrm{C}$ to $180^{\circ} \mathrm{C}$ at 4 ${ }^{\circ} \mathrm{C} / \mathrm{min}$ then $180^{\circ} \mathrm{C}$ up to $250{ }^{\circ} \mathrm{C}$ at $10^{\circ} \mathrm{C} / \mathrm{min}$. The mass spectra were recorded at 30 to $450 \mathrm{~m} / \mathrm{z}$. The chromatogram and mass spectra obtained were compared with the spectra of standard compounds that had been known in the database program on the GC-MS tools.

\section{Antioxidants activity}

The antioxidant activity test used the method of measuring the free radical scavenging activity of 2,2-diphenyl-1-picrylhydrazyl (DPPH). The measurement steps are as follows: dissolved lemongrass oil in $1 \mathrm{~mL}$ ethanol, then add $1 \mathrm{~mL}$ of $0.1 \mathrm{M}$ acetate buffer solution $(\mathrm{pH} 5.5)$ and $0.5 \mathrm{~mL}$ of DPPH $5 \times 10^{-4} \mathrm{M}$ solution, then incubated at T $20{ }^{\circ} \mathrm{C}$ for 5 minutes. The concentration of the test solution was made 1000, 500, $250 \mathrm{ppm}$. An ultraviolet spectrometer measured the absorbance of the test solution and the comparison solution at wavelengths of 497, 517, and $537 \mathrm{~nm}$. The calculation of antioxidant capacity as an absorbance reduction process against DPPH radicals uses the following formula.
$\% \mathrm{DPPH}$ reduction

Absorbance count $\lambda_{517} \mathrm{~nm}$

$$
=1-\frac{\text { The absorbance count of the test solution }}{D P P H \text { absorbance }}
$$$$
=A_{517}-\frac{A_{497-A_{537}}}{2}
$$

\section{Results and Discussion}

\section{Preparation sample (Cymbopogon nardus L.)}

The samples used in this study were lemongrass stems and leaves which were taken around the citronella oil refinery in the community of Oenenu Village, Bikomi Tengah District. Plant samples were washed, chopped, and dried for $\pm 4-5$ hours to remove impurities, expand contact between particles and reduce moisture content in the sample (Sembiring \& Manoi, 2015). The mass of the sample obtained is $\pm 22-25 \mathrm{~kg}$, while the moisture content lost during drying is $12 \%$. The citronella oil obtained through the steam-distillation method was 191.78 grams. The water content in the oil is removed by adding $\mathrm{Na}_{2} \mathrm{SO}_{4}$ (Nakahara et al., 2003) to obtain an oil yield of $45.15 \%$. Water-free citronella oil is clear yellow with a distinctive and pungent aroma. Components in citronella oil were analyzed by GC-MS and tested for bioactivity as an antioxidant.

Chemical components in citronella oil using GCMS.

Essential oil from the $C$. nardus L. plant from Oenenu Village, Bikomi Tengah District, has been characterized by GC-MS. A total of 27 components representing $92.5 \%$ of the compounds detected, of which geraniol or 2,6-Octadien-1-ol, 3,7-dimethylwere the major components $(18.82 \%)$, followed by citronellol (5.27\%) and citronellal (1.28\%). These three compounds are the main compounds contained in $C$. nardus L. All components of the compounds that have been identified can be seen in Table 1.

The chemical compound of $C$. nardus $\mathrm{L}$. citronella oil that has been characterized contains a 
different composition when compared to several studies that have been reported. Citronellal is one of the compounds that give the characteristic aroma of citronella plants (Yulvianti et al., 2014). A high percentage of geraniol compounds was reported by Nakahara et al. (2003), compared to this study (18.82\%) and other research by Mahalwal \& Ali (2003), which was $24.2 \%$. The difference in the percentage of compounds produced by this study lies in the composition of citronellal and citronellol compounds. Citronellal compounds with a percentage of $5.27 \%$ were more significant than the percentage of studies that have been reported by Nakahara et al. (2003) and Wei \& Wee (2013), namely $4.6 \%$ and not found in the reported research conducted by Mahalwal \& Ali (2003). As for citronellal compounds reported by Wei \& Wee (2013) and Mahalwal \& Ali (2003) have a greater percentage compared to this study $1.28 \%$ and by Nakahara et al. (2003) $5.8 \%$.

Table 1. Components of the characterization result of Cymbopogon nardus L.

\begin{tabular}{|c|c|}
\hline Compounds & $\%$ Area \\
\hline 2,6-Octadien-1-ol,3,7-dimethyl-(E) & 18.82 \\
\hline Napthalene, 1,2,4a,5,6,8a-hexahydro-4,7-dimethyl-1-(1-methylethyl)- & 6.26 \\
\hline 6-Octen-1-ol,3,7-dimethyl-(R) & 5.27 \\
\hline 2,6-Octadien-1-ol,3,7dimethyl-acetate & 3.84 \\
\hline Phenol,2-methoxy-4-(1-propenyl)-(E) & 3.61 \\
\hline Caryophyllene & 3.47 \\
\hline Bicyclo[4.4.0] dec-1-ene,2-isopropyl-5methyl-9-methylene & 3.41 \\
\hline D-limonene & 2.29 \\
\hline $\begin{array}{l}\text { Cyclohexanementhanol,4-ethenyl-alpha.,.alpha.,4-trimethyl-3-(1-methylethenyl)-,[1R- } \\
\text { (1.alpha.,3.alpha.,4.beta.)] }\end{array}$ & 2.06 \\
\hline Dodecane & 1.61 \\
\hline Napthalene,1,2,3,6,8a-hexahydro-4,7-dimethyl-1-(1-methylethyl)-(1S-cis) & 1.56 \\
\hline $\begin{array}{l}\text { Cyclobuta[1,2:3,4]dicyclopentene, decahydro-3a-methyl-6-methylene-1- (1-methylethyl)-, [1S- } \\
\text { (1.alpha.,3 .alpha.,3b.beta.,6a.beta.,6b.alpha.)]- }\end{array}$ & 1.43 \\
\hline Cyclohexane, 1-ethenyl-1-methyl-2, 4-bis(1-methylethenyl)-, (1.alpha. ,2.beta.,4.beta.)- & 1.47 \\
\hline 6-Octenal, 3,7-dimethyl- & 1.28 \\
\hline (+)-Epi-bicyclosesquiphellandrene & 1.13 \\
\hline 1,6-Octadien-3-ol, 3,7-dimethyl-Lynalyl isobutyrate & 1.11 \\
\hline Decanal & 1.05 \\
\hline Alpha- Caryophillene & 1.06 \\
\hline Bicyclo[2.2.1]heptane, 2,2-dimethyl-3-methylene- & 1.00 \\
\hline 1R-.alpha.-pinene & 0.86 \\
\hline Tricyclo[2.2.1.0(2,6)]heptane, 1,7,7-trimethyl- & 0.49 \\
\hline beta.-Myrcene & 0.49 \\
\hline 1,3,6-Octatriene, 3,7-dimethyl-, (Z) & 0.48 \\
\hline Caryophyllene oxide & 0.87 \\
\hline Bicyclo[2.2.1] heptan-2-ol, 1,7,7-trimethyl-, (1S-endo)- & 0.73 \\
\hline Benzene, 1,2,3,5-tetramethyl- & 0.37 \\
\hline Eugenol & 0.33 \\
\hline
\end{tabular}

In addition, this study was reported to contain D-limonene and eugenol compounds (2.29 and $0.33 \%)$ and was not identified by Nakahara et al. (2003), and a greater percentage than reported by Wei \& Wee (2013). Some of the compounds identified in this study have similarities with the compounds reported by Wei \& Wee (2013) but have different percentages.

\section{Antioxidants activity}

An antioxidant is a substance which at small concentrations, is significantly able to inhibit or prevent oxidation of the substrate caused by free radicals (Handayani et al., 2014). Free radicals are highly reactive molecules because they have unpaired electrons in their outer orbitals so that they can react with the body's cell molecules by binding to the electrons of the cell molecules. Free radicals that are generated continuously during normal metabolic processes are considered to be the cause of damage to the function of body cells, which eventually triggers degenerative diseases (Bahriul et al., 2014). The antioxidant activity of lemongrass oil was tested using the 2,2-diphenyl-1-picrylhydrazyl 
(DPPH) capture method which is based on the reduction of DPPH solution in the presence of a hydrogen donor molecule. The reduction of DPPH solution was observed by measuring the absorption at a wavelength of $518 \mathrm{~nm}$ and then calculated as the percentage of inhibition. The percentage of sample inhibition (Table 2) was measured to determine the ability of citronella oil to reduce free radicals and was compared against the standard of ascorbic acid (Bahriul et al., 2014).

Citronella oil can reduce free radicals. The four concentration variations $(125,250,500$, and 1000 ppm) of the samples showed different percent inhibition where the ability of free radical reduction increased with increasing concentration. The main component in citronella oil which has bioactivity as an antioxidant, is geraniol (18.82\%), although the percentage of bioactivity is lower than that of ascorbic acid for different concentrations. Lemongrass oil with a high monoterpene alcohol content $(40.77 \%)$ has been reported to have lower bioactivity as an antioxidant compared to standard gallic acid (Bayala et al., 2020). The level of antioxidant activity of citronella oil is known based on the calculation of the $\mathrm{IC}_{50}$ value. The $\mathrm{IC}_{50}$ value is the sample concentration needed to reduce $50 \%$ free radicals.

Table 2. Percent of sample and standard inhibition

\begin{tabular}{cccccc}
\hline \multicolumn{5}{c}{ Standard } & \multicolumn{4}{c}{ Sample } \\
\hline Concentration $(\mathrm{ppm})$ & \% Inhibition & $\mathrm{IC}_{50}(\mathrm{ppm})$ & Concentration $(\mathrm{ppm})$ & \% Inhibition & $\mathrm{IC}_{50}(\mathrm{ppm})$ \\
\hline 1.25 & 22.86 & & 125 & 5.55 & \\
2.50 & 45.33 & 2.77 & 250 & 20.44 & 6 \\
3.75 & 67.81 & & 500 & 36.92 & \\
5.00 & 89.52 & & 1000 & 73.22 & \\
\hline
\end{tabular}

Based on the calculation of the $\mathrm{IC}_{50}$ value, the minimum concentration of lemongrass to reduce $50 \%$ free radicals is $681.48 \mathrm{ppm}$. This value indicates that lemongrass oil has weak antioxidant activity $\left(\mathrm{IC}_{50}>100 \mathrm{ppm}\right)$, according to (Phongpaichit et al., 2007). The weak antioxidant activity of lemongrass oil is related to the low number of hydrogen donor groups in the principal constituents such as geraniol, citronellal, and citronellol (Figure 1) contained in lemongrass oil (Nakahara et al., 2003). Compounds with high antioxidant activity are phenolic compounds because they have many hydroxy groups (electron donors).
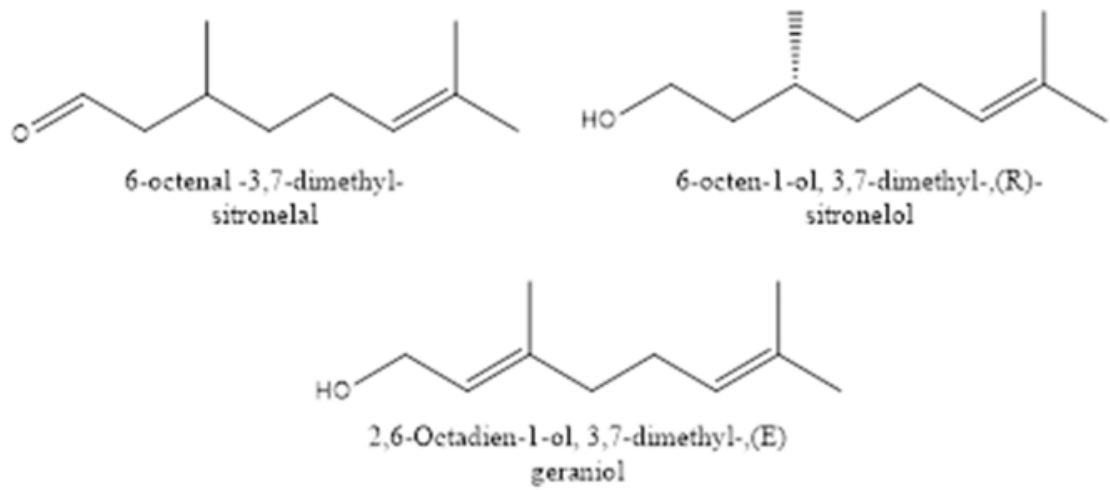

Figure 1. Structure of geraniol, citronellal, and citronellol compounds

\section{Conclusions}

Based on the results of this study, it can be concluded that citronella oil from Oenenu Village, Bikomi Tengah District contains Geraniol, Citronellol, and Citronellal compounds. The content of these compounds will support the market quality of lemongrass oil and increase the knowledge of the local community in the development and preservation of superior commodities. In addition, it is also known that lemongrass oil has the potential as an antioxidant so that it can be further developed as an alternative treatment for several types of diseases.

\section{Acknowledgment}

Thank you to DRPM University of Timor with Contract Number 02/60/LPPM/PP/2020.

\section{References}

Arcani, N. L. K. S., Sudarmaja, I. M., \& Swastika, I. K. (2017). Efektifitas ekstrak etanol serai wangi (cymbopogon nardus l) sebagai larvasida aedes aegypti. E-Jurnal Udayana Medika, 6(1), $1-4$.

Aulung, A., Rahayu, S., \& Hasque, A, N. (2014). Pengaruh ekstrak serai wangi (cymbopogon 
nardus l) terhadap kematian larva aedes aegypti. Majalah Kedokteran UKI, XXX(2), 43-47.

Bahriul, P., Rahman, N., \& Diah, A. W. M. (2014). Uji aktivitas antioksidan ekstrak etanol daun salam (Syzyngium polyanthum) dengan menggunakan 1,1-difenil-2-pikrilhidrazil. Jurnal Akademika Kimia, 3(3), 368-374.

Bayala, B., Coulibaly, A. Y., Djigma, F. W., Nagalo, B. M., Baron, S., Figueredo, G., Lobaccaro, J. M. A., \& Simpore, J. (2020). Chemical composition, antioxidant, anti-inflammatory, and antiproliferative activities of the essential oil of Cymbopogon nardus, a plant used in traditional medicine. Biomolecular Concepts, 11(1), 86-96.

Bota, W., Martosupono, M., \& Rondonuwu, F. (2015). Potensi senyawa minyak sereh wangi (Citronella oil) dari tumbuhan Cymbopogon nardus L. sebagai agen anti bakteri. Prosiding Seminar Nasional Sains Dan Teknologi (pp 18). Jakarta: Universitas Muhammadiyah Jakarta.

Handayani, V., Ahmad, A. R., \& Sudir, M.(2014). Uji aktivitas antioksidan ekstrak metanol bunga dan daun patikala (Etlingera elatior (Jack) R.M .Sm) menggunakan metode DPPH. Pharmaceutical Science Research (PSR), 1(2), 86-93.

Iskarlia, G. R., Rahmawati, L., \& Chasanah, U. (2014). Fungisida nabati dari tanaman serai wangi (Cymbopogon nardus) untuk menghambat pertumbuhan jamur pada batang karet (Hevea brasillensis Mueli, Arg). Polhasains: Jurnal Sains dan Terapan Politeknik Hasnur Banjarmasin, 3(1), 1-8.

Kolo, S. M. D., Fallo, G., \& Neno, S. D. R. (2018). Aktivitas biolarvasida ekstrak daun sirsak dan serai wangi terhadap larva nyamuk aedes aegypti. Jurnal Saintek Lahan Kering; 1(1), 1316.

Mahalwal, V. S., \& Ali, M. (2003). Volatile constituents of Cymbopogon nardus (Linn.) Rendle. Flavour and Fragrance Journal, 18(1), 73-76.
Mirghani, M. E. S., Liyana, Y., \& Parveen, J. (2012). Bioactivity analysis of lemongrass (Cymbopogan citratus) essential oil. International Food Research Journal, 19(2), 569575.

Nakahara, K., Alzoreky, N. S., Yoshihashi, T., Nguyen, H. T. T., \& Trakoontivakorn, G. (2003). Chemical composition and antifungal activity of essential oil from cymbopogon nardus (citronella grass). Japan Agricultural Research Quarterly, 37(4), 249-252.

Phongpaichit, S., Nikom, J., Rungjindamai, N., Sakayaroj, J., Hutadilok-Towatana, N., Rukachaisirikul, V., \& Kirtikara, K. (2007). Biological activities of extracts from endophytic fungi isolated from Garcinia plants. FEMS Immunology \& Medical Microbiology, 51(3), 517-525.

Sembiring, B., \& Manoi, F. (2015). pengaruh pelayuan dan penyulingan terhadap rendemen dan mutu minyak serai wangi ( Cymbopogom nardus ). Prosiding Seminar Nasional Swasembada Pangan, Politeknik Negeri Lampung (pp 447-451). Lampung: Universitas Negeri Lampung.

Setyaningsih, D., Hambali, E., \& Nasution, M. (2007). Aplikasi minyak sereh wangi (citronella oil) dan geraniol dalam pembuatan skin lotion penolak nyamuk. Jurnal Teknologi Pertanian, 17(3), 97-103.

Venkataraman, K. (1972). Wood phenolics in the chemotaxonomy of the Moraceae. Phytochemistry, 11(5), 1571-1586.

Wei, L. S., \& Wee, W. (2013). Chemical composition and antimicrobial activity of Cymbopogon nardus citronella essential oil against systemic bacteria of aquatic animals. Iranian Journal of Microbiology, 5(2), 147-152.

Yulvianti, M., Sari, R. M., \& Amaliah, E. R. (2014). Pengaruh perbandingan campuran pelarut $n$ heksana- etanol terhadap kandungan sitronelal hasil ekstraksi serai wangi (Cymbopogon nardus). Jurnal Integrasi Proses, 5(1), 8-14. 